\title{
Observations On The Ecology Of Earthworms And Its Effect On The Population Dynamics Of Cellulolytic Bacteria In Soils Across Selected Habitats In Imo State University Main Campus Owerri, Nigeria
}

\author{
C. B. Ogbonna ${ }^{1,2}$ and D. P. Berebon ${ }^{1}$ \\ ${ }^{I}$ Department of Microbiology, Faculty of Biological Science, College of Natural and Applied Sciences, \\ University of Port Harcourt, P.M.B. 5323 Port Harcourt, Nigeria \\ ${ }^{2}$ Department of Animal and Environmental Biology, Faculty of Sciences, Imo State University, P.M.B. 2000 \\ Owerri, Nigeria
}

\begin{abstract}
This study was aimed at investigating the relationship between the population dynamics of earthworms and the populations of total and cellulolytic bacteria in the soil across selected sites within the Imo State University main Campus Owerri, Nigeria. Four habitats, namely, land with trees and grass cover, lawn with total grass cover, lawn with scanty grass cover and abandoned farmland where selected and composite soil samples were collected from them. After analyzing some physico-chemical properties of soil samples, the total number of bacteria in nutrient-agar and aerobic cellulolytic bacteria in cellulose-agar were counted. Assessment of bacterial cellulolytic activity was performed via measurement of clear zone around of colony. Also, earthworms were collected from the study sites and their population density, biomass, length, proportion of adults and juveniles and taxonomic features were compared among the four habitats. Result showed that the land with trees and grass cover recorded the highest total bacteria, aerobic cellulolytic bacteria, proportion of cellulolytic bacteria, worm density, worm biomass, and worm length $\left(241.4 \times 10^{4} \mathrm{cfu} / \mathrm{g}, 123.8 \times 10^{4} \mathrm{cfu} / \mathrm{g}, 51.28 \%\right.$, $37.5 \pm 10.8 \mathrm{~m}^{-2}, 5.2+2.1 \mathrm{gm}^{-2}$ and $\left.20.4+8.1 \mathrm{~cm}\right)$, followed by the lawn with total grass cover $\left(203.6 \times 10^{4} \mathrm{cfu} / \mathrm{g}\right.$, $96.8 \times 10^{4} \mathrm{cfu} / \mathrm{g}, 47.54 \%, 23.5 \pm 6.4 \mathrm{~m}^{-2}, 3.3 \pm 1.8 \mathrm{gm}^{-2}$ and $\left.13.4 \pm 6.2 \mathrm{~cm}\right)$, the lawn with scanty grass cover $\left(127.3 \times 10^{4} \mathrm{cfu} / \mathrm{g}, 34.7 \times 10^{4} \mathrm{cfu} / \mathrm{g}, 27.26 \%, 16.7 \pm 5.3 \mathrm{~m}^{-2}, 2.3 \pm 0.5 \mathrm{gm}^{-2}\right.$ and $\left.11.9 \pm 2.3 \mathrm{~cm}\right)$ and the abandoned farmland $\left(106 \times 10^{4} \mathrm{cfu} / \mathrm{g}, 23.8 \times 10^{4} \mathrm{cfu} / \mathrm{g}, 22.37 \%, 11.8 \pm 4.4 \mathrm{~m}^{-2}, 1.6 \pm 0.3 \mathrm{gm}^{-2}\right.$ and $\left.12.8 \pm 3.1 \mathrm{~cm}\right)$. Mean ratio of clear zone diameter to colony were $1.60 \pm 0.42,1.3 \pm 0.36,0.8 \pm 0.22$ and $1.93 \pm 0.25$ for the land with trees and grass cover, the lawn with total grass cover, the lawn with scanty grass cover and the abandoned farmland, respectively. Higher ability of the cellulolytic bacteria in the abandoned farmland and the land with trees and grass cover may be due to species diversity. All four habitats had a higher proportion of adult earthworms than juvenile earthworms in an approximate ratio of 3:1, adult: juvenile. Finally, the taxonomic status of the earthworms in all four habitats suggested that they may belong to the same species. However, species identification was not attempted.
\end{abstract}

Keywords: Cellulolytic bacteria, Ecology, Earthworms, Imo State University main Campus

\section{Introduction}

Earthworms are the members of the class Oligochaeta of phylum Annelida and are one of the major macrofauna of soil. In general, earthworms possess the following principal systematic features: bilateral symmetry, external segments with a corresponding internal segmentation, setae borne on all segments except the first two, and possession of an outer layer of circular muscles and an inner layer of longitudinal muscles. The alimentary canal is basically an anterior-posterior tube with excretion through specialized organs (nephridia).

Respiration is mainly cuticular. Earthworms are hermaphroditic or parthenogenetic [1]. Earthworms have the ability to improve soil structure, contribute to the breakdown of organic matter and release plant nutrients $[1,2,3]$. They have been suggested as useful indicators of healthy soil ecosystems [4]. Earthworms present in an ecosystem have also been shown to decrease the severity of the soil borne bacterial and fungal plant diseases $[5,2]$. They are also being used as key bio indicator organisms for testing the toxicity of chemicals and pollutants in soil $[6,7,8,9,10,11]$. Earthworms can be used in waste management, preparation of biofertilizer through vermicomposting, minimization of environmental pollution through vermicomposting, bioaccumulation of toxic residues agrochemicals (metals) and in medicine in the treatment of wound, piles, chronic boils, sore throat, hernia, respiratory ailments, jaundice and rheumatic arthritis [12, 3].

Earthworms fall into three distinct ecological groups based on feeding and burrowing habits. Epigeic (litter dwelling) earthworms live and feed in surface litter. They move horizontally through leaf litter or compost with little ingestion of or burrowing into the soil. These worms are characteristically small and are not found in low organic matter soils. Lumbricus rubellus is an example of epigeic species. Endogeic (shallow dwelling) 
earthworms are active in mineral topsoil layers and associated organic matter. They create a three-dimensional maze of burrows while consuming large quantities of soil. The genuses Diplocardia and Aporrectodea have endogeic life habits. Anecic (deep burrowing) earthworms live in permanent, nearly vertical burrows that may extend several feet into the soil. They feed on surface residues and pull them into their burrows. Lumbricus terrestris is an example of an anecic species [13]. The population of earthworms is influenced by the availability and quality of food sources, soil organic matter, soil type, depth to a restrictive layer, soil $\mathrm{pH}$, soil moisture and internal drainage, rainfall and temperature, predation, parasitism and earthworm introduction (USDA, 2001). Many management practices such as tillage, crop rotations and cover crops, fertilizers, pesticides, irrigation and drainage, and worm seeding (inoculation) affect earthworm populations because they change one or more of the environmental factors listed above [14].

Earthworms interact intensively with microorganisms and other soil invertebrates within their drilosphere, strongly affecting decomposition processes, accelerating the stabilization of organic matter, and greatly modifying its physical and biochemical properties $[1,15,16,17]$. They are involved in the indirect stimulation of microbial populations, modification of microbial diversity and activity through stimulation, digestion, and dispersion in their casts [18, 19, 20, 21, 22, 23, 24, 25].

Cellulose is the most abundant biopolymer in the world and can be found in plant matter and most organic wastes in the environment. It is a linear polysaccharide which is constructed from monomers of Glucose bound together whit 1-4 glucosidal linkage [26]. Cellulose decomposition is an indispensable process for carbon cycle in nature [27]. Cellulose hydrolysis is also the key process for bioconversion of cellulosic materials [28].

The decomposition of cellulose bearing compounds in soils is a useful and beneficial biological process that earthworms in conjunction with different microorganisms (such as fungi and bacteria) are involved in it. Each factor which affects the number and activity of decomposing macro and micro organisms will have influence the cellulose decomposing intensity [29]. A number of studies have enumerated soil cellulolytic bacteria on agar plates for the assessment of cellulolytic activity [30, 31]. To the best of our knowledge, there has not been any published report on the effect of earthworms on the population dynamics of cellulolytic bacteria in the soil. The aim of this study was to investigate the relationship between the population dynamics of earthworms and the populations of cellulolytic bacteria across selected sites within the Imo State University main Campus, Owerri.

\subsection{Site description}

\section{Materials And Methods}

This investigation was carried out at four different habitats within the Imo State University main Campus in Owerri, Nigeria. The Campus is approximately $07^{\circ} 02^{\prime} \mathrm{E}$ longitude and $05^{\circ} 40^{\prime} \mathrm{N}$ latitude, which falls within the tropical rain forest zone of Nigeria. The zone is characterized by annual rainfall levels of more than $2000 \mathrm{~mm}$ [32]. The two major seasons in the area are the dry season which is experienced during OctoberMarch and rainy season which lasts from April- September. There is usually a dry period in August popularly referred to as "August break" and a period of dry cold and dusty wind popularly known as "harmattan" in January. The Campus is characterized by different habitats such as; Relatively undisturbed land with trees and grass cover, Relatively undisturbed lawns with total grass cover, Modified lawns with total grass cover, Disturbed lawns with scanty grass cover, Abandoned farmlands, Cultivated farmlands, Built- up areas, etc. For the purpose of this research, four habitats (land with trees and grass cover, lawn with total grass cover, lawn with scanty grass cover and abandoned farmland) were selected.

\subsection{Collection of soil samples from the study sites}

A maximum of ten throws of the quadrat $\left(1 \mathrm{~m}^{2}\right)$ were made in each of the selected habitats. Composite soil samples (per frame area) were collected from each experimental site. The samples were sieved $(2 \mathrm{~mm})$ and stored field moist in polyethylene bags at $5^{\circ} \mathrm{C}$ until they were analyzed.

\subsection{Determination of some physicochemical parameters of soil in the study sites}

Accordingly, soil $\mathrm{pH}$, soil moisture and soil organic matter contents were determined using the methods described in AOAC [33]. Total nitrogen as nitrate and available phosphorous were analyzed using the spectrophotometric method described by Anderson and Ingram [34]. Soil potassium was also analyzed using the method described by Olsen and Sommers et al. [35].

\subsection{Enumeration of aerobic cellulolytic bacteria (ACB) and total bacteria (TB)}

The soil samples were serially diluted from $1: 10$ to $10^{-6}$ dilutions using sterile normal saline as a blank. The number of total bacteria and aerobic cellulolytic bacteria in the soil across selected sites were determined by plating dilutions $10^{-3}$ to $10^{-4}$ in triplicates using the spread plate technique on nutrient agar and a modified cellulose agar medium of Hans [36] respectively. The cellulose medium is composed of the following in gram per litre of distilled water: $0.5 \mathrm{~g}$ of $\mathrm{K}_{2} \mathrm{HPO}_{4}, 0.5 \mathrm{~g}$ of $\mathrm{KH}_{2} \mathrm{PO}_{4}, 1.0$ of $\left(\mathrm{NH}_{4}\right)_{2} \mathrm{SO}_{4}, 0.1 \mathrm{~g}$ of $\mathrm{MgSO}_{4} .7 \mathrm{H}_{2} \mathrm{O}, 0.1$ of 
$\mathrm{CaCl}_{2}, 6.0 \mathrm{~g}$ of $\mathrm{NaCl}, 0.1 \mathrm{~g}$ of yeast extract, $10 \mathrm{~g}$ of carboxy methyl cellulose powder and $20 \mathrm{~g}$ of agar. After 2 weeks of incubation at $35^{\circ} \mathrm{C}$, the numbers of visible colonies in the plates were recorded. To recognize the cellulolytic colonies from the others, the plates were flooded with $1.0 \%$ Congo red zymogram stain for 30 minutes followed by counter staining with $1 \mathrm{M} \mathrm{NaCl}$ solution for 10-15 minutes. Clear zones were observed around the colonies which were able to decompose cellulose. Finally, the ratios of clear zone diameter to colony diameter [cellulolytic activities] were measured. Bacteria numeration was expressed in $\mathrm{cfug}^{-1}$ (cfug $^{-1}$ of dry soil $=\mathrm{CFU} /$ plate $\mathrm{x}$ dilution factor $\mathrm{x}$ 1/aliquot).

\subsection{Collection of Earthworms}

Worms were collected (per frame area) after they had been driven out from the ground with $0.5 \%(\mathrm{v} / \mathrm{v})$ formalin solution. The $0.5 \%(\mathrm{v} / \mathrm{v})$ formalin solution was prepared in the field by adding $50 \mathrm{ml}$ of $40 \%(\mathrm{v} / \mathrm{v})$ formalin to 8 litre of water contained in a 10 litre capacity sprinkler. This 8 litre formalin- water solution was sprinkled evenly in to a frame area. Earthworms were collected via digging and hand sorting, and placed in already labelled sampling containers containing $50 \%(\mathrm{v} / \mathrm{v})$ ethanol for worm preservation. After collection, worms were kept in the laboratory (with a temperature of around $20^{\circ}-25^{\circ} \mathrm{C}$ ) until they were analyzed.

\subsection{Determination of population parameters of earthworms in the study sites}

Density of earthworms was calculated as the number of individuals present per meter square. Biomass of worms was determined in an electric balance with $0.01 \mathrm{gm}$ accuracy and values are given on a fresh weight basis. The length of earthworms was obtained using a string. The string was laid along the length of an earthworm. Curves were also created along the string to fit in to the curves along the length of the worm. Both the anterior and posterior ends of the earthworm were marked on the string. The string was stretched along a glass centimetre rule and the worm length was noted from the rule. The maturity classes (adults and juveniles) of the earthworms were determined based on the presence or absence of visible clitellum. Worms with clitellum were considered adult and 'vice versa'. Finally, some morphologic features of the earthworms in the study sites were identified.

\subsection{Physicochemical properties of soil in the study sites}

\section{Results}

The average soil $\mathrm{pH}$ values, soil moisture, soil organic matter, soil total nitrogen, soil phosphorous and soil potassium contents in the study sites are shown in table 1 below. Soil $\mathrm{pH}$ in all the habitats was acidic, with a $\mathrm{pH}$ range of 4.4-6.2 across the sites. Abandoned farmland was the most acidic with an average $\mathrm{pH}$ of 5.0 \pm 0.4 , followed by the lawn with total grass cover and the lawn with scanty grass cover with $\mathrm{pH}$ of $5.3 \pm 0.4$ and $5.3 \pm 0.9$, respectively. The land with trees and grass cover had the highest $\mathrm{pH}$ of $5.7 \pm 0.4$. Soil moisture content ranged from 9.7-28.0\% across the study sites. The land with trees and grass cover had the highest soil moisture $(27.6 \pm 0.4 \%)$, followed by the lawn with total grass cover $(22.3 \pm 0.7 \%)$, lawn with scanty grass cover $(10.3 \pm 0.6 \%)$ and abandoned farmland $(10.4 \pm 0.8 \%)$. Soil organic matter ranged from $1.9-7.3 \%$ across the study sites. The land with trees and grass cover had the highest soil organic matter $(6.10 \pm 1.2 \%)$, followed by the lawn with total grass cover $(4.80 \pm 0.9 \%)$, lawn with scanty grass cover $(3.10 \pm 0.3 \%)$ and abandoned farmland $(2.20 \pm 0.6 \%)$. Soil total nitrogen ranged from $0.09-1.01 \%$ across the study sites. The land with trees and grass cover had the highest soil nitrogen $(0.81 \pm 0.2 \%)$, followed by the lawn with total grass cover $(0.64 \pm 0.3 \%)$, lawn with scanty grass cover $(0.34 \pm 0.2 \%)$ and abandoned farmland $(0.29 \pm 0.5 \%)$. Soil phosphorous ranged from 0.09 $0.57 \%$ across the study sites. The land with trees and grass cover had the highest soil phosphorous $(0.53 \pm 0.04 \%)$, followed by the lawn with total grass cover $(0.38 \pm 0.04 \%)$, lawn with scanty grass cover $(0.22 \pm 0.01 \%)$ and abandoned farmland $(0.12 \pm 0.03 \%)$. Soil potassium ranged from $0.32-0.93 \%$ across the study sites. The land with trees and grass cover had the highest soil potassium $(0.91 \pm 0.02 \%)$, followed by the lawn with total grass cover $(0.72 \pm 0.02 \%)$, lawn with scanty grass cover $(0.53 \pm 0.04 \%)$ and abandoned farmland $(0.35 \pm 0.03 \%)$.

Table 1: Physicochemical parameters of soil in the study sites

\begin{tabular}{|l|c|c|c|c|}
\hline Physicochemical Parameter & $\begin{array}{c}\text { Land with tree and } \\
\text { grass cover }\end{array}$ & $\begin{array}{c}\text { Lawn with total grass } \\
\text { cover }\end{array}$ & $\begin{array}{c}\text { Lawn with scanty } \\
\text { grass cover }\end{array}$ & $\begin{array}{c}\text { Abandoned } \\
\text { farmland }\end{array}$ \\
\hline Soil pH & $5.7 \pm 0.4$ & $5.3 \pm 0.4$ & $5.3 \pm 0.9$ & $5.0 \pm 0.6$ \\
Soil moisture (\%) & $27.6 \pm 0.4$ & $22.3 \pm 0.7$ & $10.3 \pm 0.6$ & $10.4 \pm 0.8$ \\
Soil organic matter (\%) & $6.10 \pm 1.2$ & $4.80 \pm 0.9$ & $3.10 \pm 0.3$ & $2.20 \pm 0.6$ \\
Soil total nitrogen (\%) & $0.81 \pm 0.2$ & $0.64 \pm 0.3$ & $0.34 \pm 0.2$ & $0.29 \pm 0.5$ \\
Soil phosphorous (\%) & $0.53 \pm 0.04$ & $0.38 \pm 0.04$ & $0.22 \pm 0.01$ & $0.12 \pm 0.03$ \\
Soil potassium (\%) & $0.91 \pm 0.02$ & $0.72 \pm 0.02$ & $0.53 \pm 0.04$ & $0.35 \pm 0.03$ \\
\hline
\end{tabular}




\subsection{Population parameters of earthworms and associated soil cellulolytic bacteria}

Table 2 below shows the population parameters of earthworms and associated total and cellulolytic bacteria groups in soils across the study sites. The land with trees and grass cover had the highest average total bacteria, and the number and proportion of cellulolytic bacteria $\left(241.4 \times 10^{4}\right.$ cfug $^{-1}, 123.8 \times 10^{4} \mathrm{cfug}^{-1}$ and $51.28 \%$ ), followed by the lawn with total grass cover $\left(203.6 \times 10^{4} \mathrm{cfug}^{-1}, 96.8 \times 10^{4} \mathrm{cfug}^{-1}\right.$ and $\left.47.54 \%\right)$, the lawn with scanty grass cover $\left(127.3 \times 10^{4} \mathrm{cfug}^{-1}, 34.7 \times 10^{4} \mathrm{cfug}^{-1}\right.$ and $\left.27.26 \%\right)$ and abandoned farmland $\left(106.4 \times 10^{4}\right.$ cfug $^{-1}, 23.8 \times 10^{4} \mathrm{cfug}^{-1}$ and $22.37 \%$ ) respectively. The ratio of clear zone diameter to colony diameter [cellulolytic activity], however, was highest in the abandoned farmland $(1.93+0.25)$, followed by the land with trees and grass cover $(1.60 \pm 0.42)$, the lawn with total grass cover $(1.3 \pm 0.3 \overline{6})$ and the lawn with scanty grass cover $(0.8 \pm 0.22)$ respectively.

Earthworm density ranged from 7.4-48.3 $\mathrm{m}^{-2}$ across the habitats. The land with trees and grass cover had the highest worm density with an average of about $37.5 \pm 10.8 \mathrm{~m}^{-2}$ followed by the lawn with total grass cover with an average worm density of $23.5 \pm 6.4 \mathrm{~m}^{-2}$. The lawn with scanty grass cover and the abandoned farmland had average worm densities of $16.7 \pm 5.3 \mathrm{~m}^{-2}$ and $11.8 \pm 4.4 \mathrm{~m}^{-2}$ respectively. Earthworm biomass ranged from $1.3-7.3 \mathrm{~g} / \mathrm{m}^{2}$ across the habitats. The land with trees and grass cover had the highest worm biomass with an average of about $5.2 \pm 2.1 \mathrm{~g} / \mathrm{m}^{2}$, followed by the lawn with total grass cover with an average earthworm biomass of $3.3 \pm 1.8 \mathrm{~g} / \mathrm{m}^{2}$. The lawn with scanty grass cover and the abandoned farmland had average worm biomasses of $2.3 \pm 0.5 \mathrm{~g} / \mathrm{m}^{2}$ and $1.6 \pm 0.3 \mathrm{~g} / \mathrm{m}^{2}$ respectively. The length of earthworms ranged from $9.6-28.5 \mathrm{~cm}$ across the habitats. The land with trees and grass cover had the highest worm length with an average length of $20.4 \pm 8.1$ $\mathrm{cm}$, followed by the lawn with total grass cover with an average worm length of $13.4 \pm 6.2 \mathrm{~cm}$. The lawn with scanty grass cover and the abandoned farmland had average worm lengths of $11.9 \pm 2.3 \mathrm{~cm}$ and $12.8 \pm 3.1 \mathrm{~cm}$ respectively.

The distribution of adult and juvenile earthworms across the four habitats is shown in table 2 below. There were more adult earthworms than juvenile worms in all the habitats studied. Abandoned farmland had more adult worms $(78.2 \%)$, followed by the lawn with scanty grass cover $(75.6 \%)$, the land with trees and grass cover $(72.8 \%)$ and the lawn with total grass cover $(71.5 \%)$ respectively. Consequently, abandoned farmland had the least proportion of juvenile earthworms $(21.8 \%)$, followed by the lawn with scanty grass cover $(24.4 \%)$. The lawn with total grass cover $(28.5 \%)$ and the land with trees and grass cover $(27.2 \%)$ had the highest proportion of juvenile earthworms. Approximately, this suggests a three to one $(3: 1)$ ratio of adults to juvenile earthworms in all the habitats investigated.

Table 2: Population parameters of earthworms and associated soil cellulolytic bacteria

\begin{tabular}{|c|c|c|c|c|}
\hline Biological parameter & $\begin{array}{l}\text { Land with trees } \\
\text { and grass cover }\end{array}$ & $\begin{array}{l}\text { Lawn with total } \\
\text { grass cover }\end{array}$ & $\begin{array}{c}\text { Lawn with } \\
\text { scanty grass } \\
\text { cover }\end{array}$ & $\begin{array}{l}\text { Abandoned } \\
\text { farmland }\end{array}$ \\
\hline TB $\left(10^{4}\right.$ cfug $\left.^{-1}\right)$ & 241.4 & 203.6 & 127.3 & 106 \\
\hline ACB $\left(10^{4}\right.$ cfug $\left.^{-1}\right)$ & 123.8 & 96.8 & 34.7 & 23.8 \\
\hline Percentage ACB (\%) & 51.28 & 47.54 & 27.26 & 22.37 \\
\hline $\begin{array}{l}\text { Clear zone diameter: colony } \\
\text { diameter ratio }\end{array}$ & $1.60 \pm 0.42$ & $1.3 \pm 0.36$ & $0.8 \pm 0.22$ & $1.93 \pm 0.25$ \\
\hline Worm density $\left(\mathrm{m}^{-2}\right)$ & $37.5 \pm 10.8$ & $23.5 \pm 6.4$ & $16.7 \pm 5.3$ & $11.8 \pm 4.4$ \\
\hline Worm biomass $\left(\mathrm{g} / \mathrm{m}^{2}\right)$ & $5.2 \pm 2.1$ & $3.3 \pm 1.8$ & $2.3 \pm 0.5$ & $1.6 \pm 0.3$ \\
\hline Worm length $(\mathrm{cm})$ & $20.4 \pm 8.1$ & $13.4 \pm 6.2$ & $11.9 \pm 2.3$ & $12.8 \pm 3.1$ \\
\hline Adult worm (\%) & 72.8 & 71.5 & 75.6 & 78.2 \\
\hline Juvenile worms (\%) & 27.2 & 28.5 & 24.4 & 21.8 \\
\hline Adult: Juvenile ratio & $3: 1$ & $3: 1$ & $3: 1$ & $3: 1$ \\
\hline
\end{tabular}

Legend: $\mathrm{TB}=$ Total Bacteria; $\mathrm{ACB}=$ Aerobic Cellulolytic Bacteria

\subsection{Morphological features of the earthworms observed in the study sites}

The observed morphologic features of earthworms in the study sites are summarized in table 3 below. The lengths of the earthworms ranged from $9.6-28.5 \mathrm{~cm}$. The worms were reddish/dark brown in colour. There were 4 pairs of chaetae (or setae) per segment in each of the worms studied. The anterior end of the worms is darker in colour than the posterior end. The anterior end is also cylindrical in shape compared to the posterior end which is dorsoventrally flattened. The dorsum is darker and round, while the venter is lighter and flattened.

The funnel-shaped prostomium, a small dorsal lobe anterior to the peristomium is present in the worms. The peristomium, first true segment which circles the mouth of the earthworms is also present. The clitellum, a swollen area located at about $1 / 4$ the length from the anterior end is present. The nephridiopore, which opens a little dorsal and anterior to the setae on each side of most segments near the anterior edge of the segments, is also present. At segment 15, there is the presence of an opening which is known as the male gonopore. The female gonopore opens at the $14^{\text {th }}$ segment while, the seminal receptacles located in segments 9 and 10 open laterally between segments $9-10$ and 10-11. After the $12^{\text {th }}$ segment, every other segment posterior to it possess a coelomic pore located in the dorsal mid-line between adjacent segments. 
Table 3: Observed morphologic features of earthworms in the study sites

\begin{tabular}{|l|l|l|}
\hline SN & Parameter & Observation \\
\hline 1. & No of segments & $102-145$ \\
2. & Length $(\mathrm{cm})$ & $9.6-28.5 \mathrm{~cm}$ \\
3. & Colour & Reddish-brown/dark brown \\
4. & Setae & 4 pairs per segment \\
5. & Anterior end & Darker, cylindrical in shape \\
6. & Posterior end & Lighter, dorsoventrally flattened \\
7. & Dorsum & Dark and rounded \\
8. & Venter & Light and flattened \\
9. & Prostomium & Present (funnel-shaped) \\
10. & Peristomium & Present (first true segment) \\
11. & Clitellum & Swollen area, near the anterior end present \\
12. & Nephridiopore & Opens a little dorsal, near the anterior edge of most segments \\
13. & Male gonopore & Opens at the $15^{\text {th }}$ segment of the worms \\
14. & Female gonopore & Opens at the $14^{\text {th }}$ segment of the worms \\
15. & Seminal receptacle pores & Opens between segments $9-10$ and $10-11$ \\
16. & Coelomic pore & Present in all segments posterior to the $12^{\text {th }}$ segment \\
\hline
\end{tabular}

\section{Discussion}

The distribution and population density of earthworms and bacteria at a specific site is the result of the interaction of a number of factors such as $\mathrm{pH}$, organic matter, nitrogen, phosphorous and potassium content, etc $[37,38,39,40,31]$. Higher total bacteria, number and proportion of cellulolytic bacteria, worm density and biomass and worm length were recorded in the land with trees and grass cover and the lawn with total grass cover than in the lawn with scanty grass cover and the abandoned farmland respectively. The above observations on various soil parameters show a more favourable soil condition for earthworms (and bacterial populations) in the land with trees and grass cover and the lawn with total grass cover than in the lawn with scanty grass cover and the abandoned farmland respectively. Also, factors such as incomplete plant cover in the scanty grass lawn and previous agricultural management practices on the abandoned farmland may have contributed to the reduced density and biomass of earthworms and consequently, bacterial populations [14].

There was a higher bacterial cellulolytic activity in the abandoned farmland and the land with trees and grass cover than in the lawn with total grass cover and the lawn with scanty grass cover respectively. This is probably due to the presence of superior cellulolytic bacterial strains, variety of the microorganisms or the type of organic matter across the study sites.

Worm length ranged from 9.6-28.5 cm across the study sites. Variation in worm length across the study sites may have resulted from factors such as age factor [adults are generally longer than juveniles] or species factor [some species are longer than others]. With regards to age distribution, there was a predominance of adult earthworms in all the study sites. This is possible because juvenile worms are generally more difficult to locate than their adult counterparts during worm collection [41]. Also, juvenile earthworms may be more susceptible to harsh environmental conditions than their adult counterparts. Some of the taxonomic features of the earthworms recorded across the study sites suggest that they may belong to the same species. However, species identification was not attempted.

\section{Conclusion}

Microorganisms are the main agents of biochemical decomposition, whereby earthworms are involved in the indirect stimulation of microbial populations through fragmentation of organic matter, that is, by increasing the surface area available for microbes. Earthworms also modify the microbial populations through digestion, stimulation, and dispersion in casts. Therefore, it is necessary to establish the effects of earthworms on microorganisms, because whether the earthworms stimulate or depress the microbiota, or modify the structure and function of microbial communities, they can have quite different effects on the rates and form of decomposition of organic matter [16]. This study suggests that there may be a positive correlation between the population dynamics of earthworms and the population of cellulolytic bacteria in the soil.

\section{References}

[1] Edwards, C. A., and Bohlen, P. J. (1996). Biology and Ecology of Earthworms. Chapman and Hall, London.

[2] Elmer, W.H. (2012). Using earthworms to improve soil health and suppression diseases. The Connecticut Agricultural Experiment Station (www. ct.gov/case).

[3] Grdisa, M., Grsic, K., and Grdisa, M.D. (2013). Earthworms- role in soil fertility to the use in medicine and as food. International Journal of Science 10: 38-45.

[4] Edwards, C.A. and Bohlen, P.J. (1992). The effects of toxic chemicals on earthworms. Review in Environmental Contamination \& Toxicology, 125: 23-99.

[5] Stephens, P.M., Davoren, C. W., Doube, B.M., Ryder, M.H., Benger, A.M. and Neate, S.M. (1993). Reduced severity of Rhizoctonia solania diseases on wheat seedlings associated with the presence of the earthworms Aporrectodea trapezoids (Lumbricidae). Soil Biology and Biochemistry 25: 1477-1484. 
[6] Bouche, A. (1992). Earthworm species and ecotoxicological studies. In: Greg Smith, P.W. Beaker, H., Edwards, P.J. and Heimbech, F. (eds). Ecotoxicology of earthworms. Intercepts, Andover, pp. 20-35.

[7] Hirano, T., and Tamar, K. (2011). Earthworms and Soil pollutants. Sensors 11: 11157-11167.

[8] van Gestel, A.M.C., Koolhaas, J.E., Hamers, T., van Hoppe, M., van Roovert, M., Korsman, C., and Reinecke, S.A. (2013). Effects of metal pollution on earthworm communities in a contaminated floodplain area: Linking biomarker, community and functional responses. Environmental Pollution 157: 895-903

[9] Adebayo, O.A. (2005). Stress indicators in earthworms inhabiting a crude oil contaminated ecosystem. acta SATECH 2(1): $1-5$.

[10] Oboh, B.O., Adeyinka, Y., Awonuga, S., and Akinola, M.O. (2007). Impact of soil types and petroleum effluents on the earthworm, Eudrilus eugeniae. Journal of Environmental Biology 28(2): 209-212.

[11] Paoletti, M.G. (1999). The role of earthworms for assessment of sustaninability and as bioindicators. Agriculture, Ecosystems and Environment 74: 137-155.

[12] Sheela, S., and Khimiya, S. (2013). Vermicompost to save our agricultural land. Research Journal of Agriculture and Forestry Sciences 1(4): 18-20.

[13] Coleman, D.C., and Crossley, D.A. (1996). Fundamentals of soil ecology. Academic Press, San Diego, CA.

[14] USDA (2001). Agricultural management effects on earthworms population. Technical note, No. 11: soil quality institute (www. soil. usda.gov/sqi).

[15] Domínguez, J. (2004). State of the art and new perspectives on vermicomposting research. In: Edwards, C.A. (ed.), Earthworm Ecology 2nd Edition, 401-424. 2nd ed. CRC Press, Boca Raton, FL.

[16] Dominguez, J. (2011). The microbiology of vermicomposting. Taylor and Francis Group, LLC, pp: 1-14.

[17] Edwards, C.A., Domínguez, J. and Arancon, N.Q. (2004). The influence of vermicomposts on plant growth and pest incidence. In Shakir, S.H. and Mikhail, W.Z.A. (eds), Soil Zoology for Sustainable Development in the 21 st Century, 397-420, El Cairo, Egypt.

[18] Domínguez, J., Parmelee, R. W., and Edwards, C. A. (2003). Interactions between Eisenia andrei (Oligochaeta) and nematode populations during vermicomposting. Pedobiologia 47:53-60.

[19] Adnan, M., Joshi, N. (2013). The uniqueness of microbial diversity from the gut of earthworm and its importance. Journal of Microbiology and Biotechnology 3(1): 111-115.

[20] Brown, G.G. (1995). How do earthworms affect microfloral and faunal community diversity? Plant Soil 170:209-231.

[21] Karsten, G. R., and Drake, H. L. (1995). Comparative assessment of the aerobic and anaer-obic microflora of earthworm guts and forest soils. Applied and Environmental Microbiology 61:1039-1044.

[22] Horn, M. A., Ihssen, J., Matthies, C., Schramm, A., Acker, G., and Drake, H. L. (2005). N 2 O-producing bacteria isolated from the gut of the earthworm Aporrectodea caliginosa. Int. J. Syst. Evol. Microbiol. 55:1255-1265.

[23] Monroy, F., Aira, M., and Domínguez, J. (2008). Changes in density of nematodes, protozoa and total coliforms after transit through the gut of four epigeic earthworms (Oligochaeta). Applied Soil Ecology 39:127-132.

[24] Monroy, F., Aira, M., and Domínguez, J. (2009). Reduction of total coliform numbers during vermicomposting is caused by shortterm direct effects of earthworms on microorganisms and depends on the dose of application of pig slurry. Sci. Total Environ. 407:5411-5416.

[25] Eastman, B. R., Kane, P. N., Edwards, C. A., Trytek, L., Gunadi, B., Stermer, A. L., and Mobley, J. R. (2001). The effectiven ess of vermiculture in human pathogen reduction for USEPA biosolids stabilization. Compost Sci. Util. 9:38-49.

[26] Bobbie, J., and Leatherwood, J.M. (1976). Derepressed synthesis of cellulose by cellulomonas. Journal of Bacteriology 128: 609615 .

[27] Donnelly, P.K., Entry, J.A., Crawford, D.L., and Cromack, K. (1990). Cellulose and lignin degradation in forest soils in response to moisture, temperature and acidity. Microbial Ecology 20: 289-295.

[28] Dorothy, M.H., and Gibson, A.H. (1985). Cellulose decomposition and associated nitrogen fixation by mixed cultures of Cellulomonas gelida and Azospirillum species or Bacillus macerans. Applied and Environmental Microbiology 50(4): 1021-1026.

[29] Lynd, R., Lee, J., Weimer, P., Van Zyl, W.H., and Pretorius, S. (2002). Microbial cellulose utilization: Fundamentals and Biotechnology. American Society of Microbiology 66(3): 506-577.

[30] Ronald, M.T., and Peter J.W. (1982). Use of congo red polysaccharide interactions in enumeration and characterization of cellulolytic bacteria from the Bovine Rument. Applied and Environmental Microbiology 43(4).

[31] Hatami, S., Alikhani, H.A., Besharati, H., Salehrastin, N., Afrousheh, M., and Yazdani, J.M. (2008). Investigation on aerobic cellulolytic bacteria in some of North Forest and Farming soils. American-Eurasian Journal of Agriculture and Environmental Science 3(5): 713-716.

[32] FOS, (1986). Annual abstract of statistics. Federal Office of Statistics Lagos, Nigeria p.202

[34] Anderson, J.M., and Ingram, J.S.I. (1993). Tropical soil Biology and Fertility, A handbook of Methods, seconded (AB International), Oxford.

[34] AOAC (1995). Official methods of Analysis. Association of Analytical Chemists 14th edition Alinton, Virginia 22209.

[35] Olsen, S.R., and Sommers, L.E. (1982). Phosphorous: In Page, A.L., Miller, R.H., and Keeney, D.R. (eds), Methods of soil analysis. Part 2. Soil Science Society of America. Inc., Madison, WI. p. 403-430

[36] Dubey, R.C., and Maheshwari, D.K. (2008). Practical microbiology. Chand and Company LTD. Ram Nagar, New Delhi-110055, p.385

[37] Valle, J.V., Moro, R.P., Gravin, H.M., Trigo, D., and Cosin, D.D.J. (1997). Annual dynamics of the earthworm Hormogaster elisae (Oligochaeta, Hormogastridae) in central Spain. Soil Biology and Biochemistry 29: 309-312.

[38] Senapati, B.K. (1993). Earthworm gut contents and its significance. In : Earthworm resources and vermiculture. (Ed. A. K. Ghosh). Zoological Survey of India, Kolkatta, pp. 97-99.

[39] Phillipson, J., Abel, R., Steel, J., and Woodell, S.R.J. (1976). Earthworms and the factors governing their distribution in an English beech wood. Pedobiologia 16: 258-285.

[40] Baker, G.H., Barret, V.J., Gerdner-Grey, R., and Buckfield, J.C. (1993). Abundance and life history of native and introduced earthworms (Annelida: Megascolicidae and Lumbricidae) in pasture soils in the mount lofty ranges, South Australia. Transactions of the Royal Society of South Australia 117: 47-53.

[41] Lee, K.E. (1985). Earthworms, their ecology and relationships with soil land use. Academic press, New York, NY. 